\title{
Optimization of Roasting Conditions for Preservation of Nutritional Quality of Terminalia catappa Almonds by Response Surface Methodology
}

\author{
Kowiou Aboudou (Corresponding author) \\ Research Unit Enzyme Engineering and Food Technology, Laboratory of Study and Research \\ in Applied Chemistry, Department of Food and Technology Engineering, University of \\ Abomey Calavi,01 BP 2009 Cotonou 01, Benin \\ E-mail: Kowiou.aboudou@yahoo.fr
}

\begin{abstract}
Sènan Vodouhe-egueh
Université Nationale des Sciences, Technologies, Ingénierie et Mathématiques d'Abomey, Ecole Nationale Supérieure de Biosciences et de Biotechnologies Appliquées, Laboratoire de Biotechnologies, Ressources Génétiques et Amélioration des Espèces Animales et Végétale, 01 BP 14 Dassa, Bénin

E-mail: vodouhesenan@yahoo.fr
\end{abstract}

Midimahu Vahid Aissi

School of Sciences and Conservation and Technology Processing of Agricultural Products, National University of Agriculture of Porto-Novo, BP 144 Sakété, Benin

E-mail: vahidaissi@yahoo.fr

Mohamed Mansourou Soumanou

Research Unit Enzyme Engineering and Food Technology, Laboratory of Study and Research in Applied Chemistry, Department of Food and Technology Engineering, University of Abomey Calavi, 01 BP 2009 Cotonou 01, Benin

E-mail: msoumanoufr@yahoo.fr

Received: June 6, $2020 \quad$ Accepted: July 26, $2020 \quad$ Published: July 30, 2020

doi:10.5296/jfs.v9i1.17137 URL: https://doi.org/10.5296/jfs.v9i1.17137 


\section{Abstract}

The optimal roasting conditions (temperature and time) of Terminalia catappa (TC) almonds allowing to preserve the nutritional quality of their almonds and oils were investigated. The almonds roasted at different temperature $\left(80-120{ }^{\circ} \mathrm{C}\right)$ for various time $(30-60 \mathrm{~min})$ using response surface methodology and oils extracted were analyzed. Effect of temperature and time on antinutritional factors and the nutritional quality of almonds and oils was evaluated then the optimum roasting conditions was determined. Results showed that oxalates, tannins and phytates contents of roasted almonds were significantly $(\mathrm{P}<0.05)$ influenced by the temperature and time. Roasting had a significant effect on oxidative stability and some quality index of oils. The optimal roasting conditions for reduction of antinutritional factors in almonds were $89.91{ }^{\circ} \mathrm{C}$ and $60 \mathrm{~min}$ with $70.37 \%$ as desirability. However, the results indicate that TC almond could be used in several areas of the food industries.

Keywords: T. catappa almonds, Roasting, Antinutritional factors, Optimization, Oil

\section{Introduction}

Nuts have been appreciated in human diets since antiquity because of their nutritional potentials (Krishnaveni, 2014). Although they are potentially nutritious, most of them are not industrialized for the lack of information (Adesioye, 1991). T. catappa almond is one of the nuts which is under-utilized and consumed after being crushed by children in India, Thailand, Malaysia, Côte d'Ivoire, Nigeria and the southern zone (coastal and Oueme) of Bénin (Ezeokonkwo, 2007; Mbah et al., 2013). Originally from the Indo-Malay region, T. catappa belongs to the family of Combretacea (Edward \& Dennis, 2016) and is naturally widely expanded in the subtropical and tropical zones of Indian Pacific oceans, where it is used as an ornamental tree along throughout fare of urban roads or public squares (dos Santos et al., 2008). According to Untwal and Kondawar (2006), its fruits are composed of a pulp enveloping the shell of a nut containing an edible almond that plays an essential role in the diet of almost everybody in the whole world (Agatemor \& Ukhun, 2006). Commonly consumed as snack, several investigators reported that it contains a significant amount of nutrients such as lipids (43.36-63.65\%), proteins (18.39-40.9\%), fibers, inorganic salts (Mg, Ca, Iron, Zinc) and vitamins (A, B2, E) (Barku et al., 2012; Biego et al., 2012; Janporn et al., 2015; Ladele et al., 2016). Its oil is mainly made of oleic acid (Safari \& Alizadeh, 2007) and also has antioxidant characteristics (Adu et al., 2015). In spite of its nutritional potential, many studies have also revealed the presence of secondary metabolites (Phytates, oxalates, tannins, saponins, flavonoids, Trypsin and phenolic compounds) in the fruit pulp as well as in the almond of T. catappa (Jonathan, 2015; Akpakpan \& Akpabio, 2012). Oduro et al. (2009) also found alkaloids and terpenes respectively in almonds of the red and yellow morphotypes. Values found for various secondary metabolites in almond varied from an author to another as it can be seen when comparing value reported for oxalates, phytates and tannins (Aduwamaib, 2006). Indeed, Akpakpan \& Akpabio (2012) reported a level of 26,40 mg/100g and 39,40 $\mathrm{mg} / 100 \mathrm{~g}$ respectively in oxalates and tannins while Adesina (2015) found a value of 3,25 $\mathrm{mg} / 100 \mathrm{~g}, 1,25 \mathrm{mg} / 100 \mathrm{~g}$ and $8,12 \mathrm{mg} / 100 \mathrm{~g}$ respectively in oxalates, tannins and phytates. Similarly, Monthan (2015) reported a level of 2,110 mg/100g, 64,9 mg GAE/g and 2,3 


\section{Macrothink}

TIU/mg in phytates, phenolic compounds and Trypsin inhibition activity respectively. The bioavailability of some essential nutrients could be reduced because of the presence of these antinutritional factors (Deokule, 2009). For example, phytic acid is known as a major inhibitor of absorption of iron, calcium, zinc and phosphorus (Shan \& Davis, 1994). Tannins forms insoluble complexes with proteins, carbohydrates and lipids (Abara, 2003), while trypsin inhibitors could reduce protein digestibility and cause hypertrophy of the pancreas (Liener, 1994). These anti-nutritional factors present in T. catappa almond should therefore be eliminated or minimized in order to utilize its entire nutritional potential. The main methods of reducing or eliminating anti-nutritional factors and improving the nutritional quality of almonds are scalding, germination, bleaching, roasting, steaming, microwave and the use of chemicals products such as hydrochloric acid, acetic acid, calcium hydroxide (Satinder Kaur, 2011; Arinola \& Adesina, 2014). Recently, the reduction trends of these factors were studied by Adesina (2015), Monthana et al. (2015) and Makinde \& Oladunni (2015). Different treatments used by these authors often have various effects on antinutritional factors and bioavailability of nutrients. Significant reductions in oxalates, phytates and tannins but also in nutrients (vitamins and essential amino acids) have been observed in roasted almonds of T. catappa (Makinde \& Oladunni, 2016), bambara groundnuts (Ndidi et al., 2014), African Walnut (Arinola \& Adesina, 2014), peanut and sesame seed (Embaby, 2010) and Treculia africana seed (Ijeh et al., 2011). Alonso et al. (2000) also reported a significant decreasing of tannins and polyphenols due to thermal processing methods. Furthermore, oxidative stability is a significant parameter that affect oil quality mainly when used for frying due to the temperature and heating duration (Kachel-jakubowska et al., 2015). Modifications of oxidative stability occurring through frying negatively affect the nutritient contents and organoleptic qualities of a fried food (Przybylski \& Eskin, 2006). Lee et al. (2004) reported that color, phospholipids, phosphorus, tocotrienol and tocopherol contents of safflower oils differed with roasting conditions (140-180 $\left.{ }^{\circ} \mathrm{C}\right)$. According to Anjum et al. (2006), a significant rise in free fatty acid, saponification, p-anisidine, conjugated diene, conjugated triene, color and density has been observed in sunflower oil obtained from roasted seeds in microwave roasting periods of 10 and $15 \mathrm{~min}$. In this present study, the objectives were: (1) to optimize the temperature and time of roasting for the reduction of antinutritional factors by response surface methodology (RSM); and (3) examine the influence of various roasting conditions on the nutritional quality of almonds and the quality and oxidative stability of the recovered oils.

\section{Material and Methods}

\subsection{Samples}

Mature T. catappa fruits of red morphotype were collected from coastal zone of Benin between August 2018 and September 2018. They were sun dried for one week, shelled and separated from their hulls manually by using a hammer (Mbah et al., 2013). The almonds were then kept in food bags and stored in the refrigerator at $5^{\circ} \mathrm{C}$ for analysis.

\subsection{Roasting}

Almond kernels were roasted in a forced air convection oven (Chung Pu machinery Co., Ltd. 


\section{Macrothink}

Taichung, Taiwan) and under the conditions selected for each experiment. Thirteen (13) trials with $150 \mathrm{~g}$ of almond were done using different temperatures and incubations time. In this process, the sample of each almond was spread in a mesh tray of stainless steel and placed in the center of the oven. The roasted kernels were cooled using the desiccator and vacuum bagged then stored at $4{ }^{\circ} \mathrm{C}$ until further experiments.

\subsection{Experimental Design and Statistical Analysis}

To determine the optimal parameters of roasting process, a central composite experimental design (CCD) with temperature (X1: $80-120^{\circ} \mathrm{C}$ ) and incubation time (X2: 30-60 min) as independent variables were assessed. Table 1 shows the codes and actual levels of the variables assessed. The dependent variables (responses, Y) were moisture content of almonds, protein, fat, content of oxalates, phytates, tannins, flavonoids in and content of phenolic compounds, color parameters ( $\left.\mathrm{L}^{*} \mathrm{a}^{*} \mathrm{~b}^{*}\right)$, acid, peroxide, anisidine value and Induction period of roasted almond and oil extracted. The responses were fitted using a second order polynomial model as follow:

$$
\boldsymbol{Y}^{x}-\beta_{\Omega}+\beta_{1} x_{1}+\beta_{2}^{2} x_{2}+\beta_{11} x_{1}^{2}+\beta_{22} x_{2}^{2}+\beta_{12} x_{1} x_{2}
$$

Where $\beta_{0}$ is a constant, $\beta_{1}$ and $\beta_{2}$ are linear coefficients, $\beta_{11}$ and $\beta_{22}$ are quadratic coefficients, and $\beta_{12}$ is interaction coefficient.

Table 1. The central composite experimental design used for the roasting conditions of $T$. catappa almond

\begin{tabular}{|c|c|c|c|c|}
\hline \multirow{2}{*}{ Experiment $n^{\circ}$} & \multicolumn{2}{|c|}{ Temperature $\left({ }^{\circ} \mathrm{C}, \mathrm{X}_{1}\right)$} & \multicolumn{2}{|c|}{ Time $\left(\min , \boldsymbol{x}_{2}\right)$} \\
\hline & Coded & Actual & Coded & Actual \\
\hline 1 & -1 & 100 & -1 & 60 \\
\hline 2 & 1 & 80 & 1 & 60 \\
\hline 3 & 0 & 100 & 0 & 45 \\
\hline 4 & -1 & 100 & -1 & 30 \\
\hline 5 & 0 & 100 & 0 & 45 \\
\hline 6 & 0 & 100 & 0 & 45 \\
\hline 7 & 1 & 120 & 1 & 60 \\
\hline 8 & -1 & 120 & -1 & 45 \\
\hline 9 & 1 & 120 & 1 & 30 \\
\hline 10 & -1 & 80 & -1 & 45 \\
\hline 11 & 1 & 80 & 1 & 30 \\
\hline 12 & 0 & 100 & 0 & 45 \\
\hline 13 & 0 & 100 & 0 & 45 \\
\hline
\end{tabular}

\subsection{Oil Extraction}

The roasted kernels were finely ground in a domestic electric coffee-grinder (Moulinex KM1, 
Made in France) and the oil from ground samples were extracted using the AOAC Method 945.16 as described by Association of Official Analytical Chemist (AOAC, 2005). $10 \mathrm{~g}$ of each sample were packed in a muslin cloth and inserted into the Soxhlet extractor and $150 \mathrm{ml}$ of hexane was used as the extraction solvent for 5 hours. After evaporation under reduced pressure at $50{ }^{\circ} \mathrm{C}$, the oil obtained was weighed to calculate lipid content and kept at $5{ }^{\circ} \mathrm{C}$ before analyses.

\subsection{Proximate Composition of Sample}

T. catappa roasted almonds were analyzed for protein according to AOAC (1995) standard method (AOAC Official Method 950.48). Moisture content (AOAC Official Method 925.40) and lipids (AOAC Official Method 948.22) were found out following the standard methods of the Association of Official Analytical Chemists (AOAC, 1995).

\subsection{Antinutritional Analysis}

\subsubsection{Determination of Oxalates Content}

Oxalates contents were determined as described by Pearson (1976). 1g of the sample was weighed into $100 \mathrm{ml}$ conical flask. $75 \mathrm{ml}$ of $15 \mathrm{~N} \mathrm{H}_{2} \mathrm{~S}_{4}$ was added and the solution was carefully stirred with a magnetic stirrer for an hour before filtration using whatman Nol filter paper. $25 \mathrm{ml}$ of the filtered sample (extract) was then collected and titrated hot $\left(80^{\circ} \mathrm{C}-90^{\circ} \mathrm{C}\right)$ against $0.05 \mathrm{MnO}_{4}$ solution to the stage where there was a faint pink color and persisted for 30 seconds at least.

\subsubsection{Determination of Tannin Content}

Tanins content were determined by of Day and Underwood (1986) method. 1g of each sample was weighed into a centrifuge tube with $2 \mathrm{ml}$ of distilled water. It was centrifuged at $1500 \mathrm{rpm}$ for 10 minutes. The supernatant was collected and poured out into a beaker and the supernatant (extract) dispersed. One $\mathrm{ml}$ of $\mathrm{NaCo}_{3}$ and Folin Denis reagent was added in the beaker and allowed to settle. Therefore, the readings were taken at $750 \mathrm{~nm}$ using a spectrophotometer. The concentration of tannin in the sample was estimated from the standard tannic acid curve.

\subsubsection{Determination of Phytates Content}

Phytates content were determined as described by Reddy and Love (1999). $4.0 \mathrm{~g}$ of sample were soaked in $100 \mathrm{~mL}$ of $2 \% \mathrm{HCl}$ for $5 \mathrm{~h}$ and filtered. $25 \mathrm{~mL}$ of the filtrate was pipetted into a conical flask and $5 \mathrm{~mL}$ of $0.3 \%$ ammonium thiocyanate $\left(\mathrm{NH}_{4} \mathrm{SCN}\right)$ solution was added. The mixture was titrated against $0.1 \mathrm{M} \mathrm{FeCl}_{3}$ until a brownish yellow color end point that persisted for 5 min was observed.

\subsubsection{Determination of Total Phenolic Compound Content and Flavonoids}

Phenolic compounds content was also determined by the Folin-Ciocalteu methods (Singleton \& Lamuela-Raventós, 1999). Briefly, after extracting the ground samples (3 g) with $80 \%$ ethanol $(100 \mathrm{~mL})$, the extracts $(2 \mathrm{~mL})$ were mixed with $5 \mathrm{~mL}$ of Folin-Ciocalteu reagent (Merck, Darmstadt, Germany) and $10 \mathrm{~min}$ later, $0.4 \mathrm{~mL}$ of sodium carbonate $(20 \% \mathrm{w} / \mathrm{v})$ was 


\section{MInstitute ${ }^{\text {Macrothink }}$}

added. The mixture was heated to $100{ }^{\circ} \mathrm{C}$. After cooling, the absorbance at $750 \mathrm{~nm}$ was measured. Gallic acid (Sigma) was used as standard, and results were expressed as milligrams of gallic acid equivalents (GAE) per gram of dry weight sample. The aluminium chloride method was used to determine the total flavonoid content (Obadoni and Ochuko, 2001). Extract solution $(2 \mathrm{ml})$ was taken and $0.1 \mathrm{ml}$ of $1 \mathrm{M}$ potassium acetate, $0.1 \mathrm{ml}$ of $\mathrm{AlCl}_{3}$ $(10 \%), 2.8 \mathrm{ml}$ distilled water were added sequentially. The test solution was vigorously shaken. Absorbance at $415 \mathrm{~nm}$ was recorded after 30 minutes of incubation. The concentration of flavonoid in the test samples were calculated from the calibration plot and expressed as $\mathrm{mg}$ quercetin equivalent/g of sample.

\subsection{Physico-chemical Analysis of the Oil}

The color of the oil was determined using Hunter Lab Color Flex EZ spectrophotometer HUNTER COLORFLEX EZ after equilibration at room temperature. Values of the color are expressed as L (darkness/whiteness), a (greenness/redness), b (blueness/yellowness) values and yellowness index (YI). Samples were placed into a glass cup (diameter $=64 \mathrm{~mm}$ ) horizontally on the side parts. The instrument was calibrated against the standard reference white and green tiles $(\mathrm{L}=91.10, \mathrm{a}=-1.13, \mathrm{~b}=1.26, \mathrm{Y}=1.52)$. Acid value $(\mathrm{AV})$ expressed in milligrams of potassium hydroxide necessary to neutralize the free acids in $1 \mathrm{~g}$ of sample was determined following the AOCS (AOCS- Cd 3d-63, 2009). The peroxide value (PV) expressed in $\mathrm{mEq}$ of active oxygen. $\mathrm{kg}^{-1}$ of oil was found out by the reaction of oil and $3: 2$ chloroform: acetic acid with potassium iodide in darkness. The titration of the free iodine was done with a standard thiosulfate solution (AOCS-Cd8-53, 2009). The anisidine value (p-AnV) was determined following the AOCS official method (AOCS- Cd 18-90, 2009), using a UV-2401PC spectrophotometer model SHIMADZU (PG Instruments Limited, London). Rancimat test Induction time was determined using the AOCS official method (AOCS- Cd 12b-92, 2009). The oxidative stability of each sample was investigated by determining the induction period (IP) on a Rancimat apparatus, model 743 (Metrohm, Swiss Made) at $110{ }^{\circ} \mathrm{C}$, at an air flow of $20 \mathrm{~L} / \mathrm{h}$. Portions of oil $(2.5 \mathrm{~g})$ were carefully weighed into each reaction vessel and analyzed simultaneously. The IP was determined automatically by the device and expressed as hours.

\subsection{Statistical Analysis}

The analysis of variance (ANOVA) was used to determine significant differences between independent variables $(\mathrm{p}<0.05)$. All statistical analyses were carried out by employing the statistical package Minitab 14 (Minitab Inc., USA). The degrees of significance of all terms in the polynomial were determined statistically by evaluating the F-value at a probability $(\mathrm{p})$ of $0.001,0.01$, or 0.05 . Contour plots were generated to see graphically how the results change with respect to the factors and to obtain graphical representation of the response surface. The optimal conditions of roasting temperature and time were obtained with the Minitab software (version 15.1, Minitab Inc., USA). The desirability functions of RSM were used to establish the optimum roasting conditions of $T$. catappa almonds. Values of the desirability functions (d) are between 0 and 1 . The optimization and individual desirability of each response was obtained by settling the goals and boundaries and later combined them with composite desirability into a single measure (TAN et al., 2012). 


\section{Mll Macrothink}

\section{Results and Discussion}

3.1 Effect of Roasting Conditions on Moisture Content, Protein and Lipids from the Roasted T. catappa Almond

The experimental values of the moisture content, protein and lipids from the roasted $T$. catappa almond are presented in Table 2a. Analysis of variance (Table 3) showed that the models developed for the moisture content, protein and lipids were significant $(p \leq 0,001)$. It shows that each of variables (temperature and time) has a specific effect on the responses. Temperature and time, as well as their quadratic effects and their interaction are more important on the moisture content of T. catappa almonds. Temperature and time were more important on the proteins and oxalates of T. catappa almonds whereas their interaction and their quadratic effects were found not significant ( $\mathrm{p}>0.05)$. The regression coefficients of the second-order polynomial equations are given in Table 4.

The contour plots for the moisture content, protein and lipids of roasted T. catappa almond were generated from the regression equations obtained (Figure 1). During roasting, moisture content and protein of $T$. catappa declined with the increasing temperature and heating duration. These results could be linked to water evaporation during roasting process (Bolek \& Ozdemir, 2017). This allows a good and long-term preservation almonds as reported by (Anhwange \& Atoo, 2015). A high moisture content reduces the storage time and impact the quality of seeds. The moisture content obtained was lower than those found by Mbah et al. (2013) and Makinde and Oladunni (2016) but comparable to those reported by Ladele et al. (2016).

The roasting induced native protein aggregation, which could result simply from the usual loss of tertiary structure followed by (reversible) unfolding, loss of secondary structure, disulphide bond cleavage, formation of new intra-/inter-molecular interactions (Hossam \& EL-Beltagi, 2011). During roasting process, these decreases in protein content can be due to protein denaturation (Sahni et al., 1997). On the contrary, an increase in fat occurred with a decrease in the temperature and time was observed. The increase could be due to the inherent complex organic compounds which are disintegrate at high temperature to release more free fat molecules (Zhao et al., 2012; Makinde \& Oladunni, 2016). 
Table 2a. Experimental data for response parameters of T. catappa almond in relation to roasting conditions

\begin{tabular}{|c|c|c|c|c|c|c|c|c|}
\hline number & $\begin{array}{l}\text { Moistu } \\
\text { re (\%) }\end{array}$ & $\begin{array}{l}\text { Lipids } \\
\text { (\%) }\end{array}$ & $\begin{array}{l}\text { Protei } \\
\text { n (\%) }\end{array}$ & $\begin{array}{l}\text { Oxalates } \\
\text { (mg/ } 100 \\
\text { g) }\end{array}$ & $\begin{array}{l}\text { Phytate } \\
\text { s (mg/ } \\
100 \mathrm{~g})\end{array}$ & $\begin{array}{l}\text { Tannin } \\
\mathrm{s} \quad(\mathrm{mg} / \\
100 \mathrm{~g})\end{array}$ & $\begin{array}{l}\text { Phenolic } \\
\text { compounds } \\
(\mathrm{mg} / 100 \mathrm{~g})\end{array}$ & $\begin{array}{l}\text { Flavonoids(mg/ } \\
100 \mathrm{~g})\end{array}$ \\
\hline 1 & 4.22 & 60.71 & 21.52 & 2.01 & 0.61 & 0.22 & 5.62 & 0.64 \\
\hline 2 & 6.15 & 56.42 & 23.16 & 3.93 & 0.62 & 0.23 & 6.93 & 1.19 \\
\hline 3 & 4.93 & 58.24 & 21.88 & 2.83 & 0.60 & 0.22 & 6.39 & 0.72 \\
\hline 4 & 5.94 & 57.36 & 22.73 & 2.90 & 0.63 & 0.23 & 6.59 & 0.74 \\
\hline 5 & 4.86 & 58.11 & 21.84 & 2.83 & 0.54 & 0.22 & 6.38 & 0.72 \\
\hline 6 & 4.82 & 58.13 & 21.84 & 2.83 & 0.72 & 0.22 & 6.39 & 0.72 \\
\hline 7 & 3.61 & 63.45 & 19.95 & 1.88 & 0.5 & 0.17 & 4.43 & 0.45 \\
\hline 8 & 3.72 & 62.24 & 20.8 & 1.93 & 0.5 & 0.19 & 5.26 & 0.47 \\
\hline 9 & 3.94 & 61.66 & 21.16 & 1.94 & 0.5 & 0.21 & 5.29 & 0.51 \\
\hline 10 & 8.73 & 55.17 & 23.60 & 4.04 & 0.6 & 0.24 & 7.06 & 0.84 \\
\hline 11 & 10.33 & 53.32 & 24.82 & 4.57 & 0.6 & 0.24 & 7.42 & 1.02 \\
\hline 12 & 4.84 & 58.01 & 21.86 & 2.83 & 0.6 & 0.22 & 6.38 & 0.72 \\
\hline 13 & 4.81 & 58.14 & 21.86 & 2.83 & 0.6 & 0.22 & 6.39 & 0.72 \\
\hline
\end{tabular}

Table 3. Analysis of variance for qualities of $T$. catappa almond

\begin{tabular}{|c|c|c|c|c|c|c|c|c|c|}
\hline \multirow[b]{2}{*}{ Source } & \multirow[b]{2}{*}{ Df } & \multicolumn{8}{|c|}{ Sum of square } \\
\hline & & $\begin{array}{l}\text { Moisture } \\
(\%)\end{array}$ & $\begin{array}{l}\text { Lipids } \\
(\%)\end{array}$ & $\begin{array}{l}\text { Protein } \\
(\%)\end{array}$ & $\begin{array}{l}\text { Oxalates } \\
(\mathrm{mg} / \quad 100 \\
\mathrm{g})\end{array}$ & $\begin{array}{l}\text { Phytates( } \\
\mathrm{mg} / \quad 100 \\
\mathrm{~g})\end{array}$ & $\begin{array}{l}\text { Tannins } \\
(\mathrm{mg} / \quad 100 \\
\mathrm{g})\end{array}$ & $\begin{array}{l}\text { Phenolic } \\
\text { compounds } \\
(\mathrm{mg} / 100 \mathrm{~g})\end{array}$ & $\begin{array}{l}\text { Flavonoids } \\
(\mathrm{mg} / 100 \mathrm{~g})\end{array}$ \\
\hline $\begin{array}{l}\text { Regression } \\
\text { model }\end{array}$ & 5 & $45.98 * * *$ & $\begin{array}{l}97.11 * * \\
*\end{array}$ & $18.97 * * *$ & $8.57^{* * *}$ & $0.02 * * *$ & $0.004 * * *$ & $8.12^{* * *}$ & $0.46^{* *}$ \\
\hline Linear & 2 & $37.99 * * *$ & $95.66^{* * *}$ & $18.58 * * *$ & $8.09^{* * *}$ & $0.01 * * *$ & $0.004 * * *$ & $7.78^{* * *}$ & $0.44 * * *$ \\
\hline Square & 2 & $4.41^{* * *}$ & 1.02 & $0.33^{*}$ & $0.40^{*}$ & $0.001 * * *$ & $0.0002 * * *$ & $0.31^{*}$ & 0.011 \\
\hline Interaction & 1 & $3.57 * * *$ & 0.35 & 0.06 & 0.08 & $0.0001 * *$ & $0.0001 * * *$ & 0.03 & 0.014 \\
\hline $\begin{array}{l}\text { Residual } \\
\text { error }\end{array}$ & 7 & 0.44 & 0.92 & 0.18 & 0.27 & 0.0004 & 0.00001 & 0.13 & 0.05 \\
\hline Lack of fit & 3 & 0.44 & 0.92 & 0.18 & 0.27 & 0.00004 & 0.00001 & 0.13 & 0.05 \\
\hline Pure error & 4 & 0.00 & 0.00 & 0.00 & 0.00 & 0.00 & 0.00 & 0.00 & 0.00 \\
\hline Total & 12 & 46.43 & 98.04 & 19.16 & 8.85 & 0.01 & 0.004 & 8.26 & 0.51 \\
\hline $\mathbf{R}^{2}$ & & 0.99 & 0.99 & 0.99 & 0.97 & 0.99 & 0.99 & 0.98 & 0.90 \\
\hline
\end{tabular}

$*, * *, * * *$ Significant at $\mathrm{p}<0.05, \mathrm{p}<0.01$, and $\mathrm{p}<0.001$, respectively. 


\section{Macrothink}

Journal of Food Studies

ISSN 2166-1073 2020, Vol. 9, No. 1

Table 4. Regression coefficients of the second-degree polynomial for the relationship between roasting conditions and changes in the quality of T. catappa almond

\begin{tabular}{|c|c|c|c|c|c|c|c|c|}
\hline Coefficient & Moisture & Lipids & Protein & Oxalates & Phytates & Tannins & $\begin{array}{l}\text { Phenolic } \\
\text { compounds }\end{array}$ & Flavonoids \\
\hline$\overline{\beta_{0}}$ & $4.87 * * *$ & $58.17 * * *$ & $21.89 * * *$ & $2.76 * * *$ & $0.57 * * *$ & $0.222 * * *$ & $6.36 * * *$ & $0.69 * * *$ \\
\hline $\boldsymbol{\beta}_{1}$ & $-2.28 * * *$ & $3.74 * * *$ & $-1.61 * * *$ & $-1.13 * * *$ & $-0.04 * * *$ & $-0.024 * * *$ & $-1.07 * * *$ & $-0.26 * * *$ \\
\hline$\beta_{2}$ & $-1.04 * * *$ & $1.38 * * *$ & $-0.70 * * *$ & $-0.26^{*}$ & $-0.01 * * *$ & $-0.009 * * *$ & $-0.38 * * *$ & 0.001 \\
\hline$\beta_{11}$ & $1.15^{* * *}$ & 0.16 & 0.21 & $0.38^{*}$ & $0.020 * * *$ & $-0.009 * * *$ & -0.15 & 0.015 \\
\hline$\beta_{22}$ & 0.04 & 0.50 & 0.17 & -0.14 & $0.006 * *$ & $-0.004^{* *}$ & $-0.21^{*}$ & 0.051 \\
\hline $\boldsymbol{\beta}_{12}$ & $0.94 * * *$ & -0.29 & 0.12 & 0.14 & $0.006^{* *}$ & $-0.006^{* * *}$ & -0.09 & -0.060 \\
\hline
\end{tabular}

$*, * * * * *$ Significant at $\mathrm{p}<0.05, \mathrm{p}<0.01$, and $\mathrm{p}<0.001$, respectively.
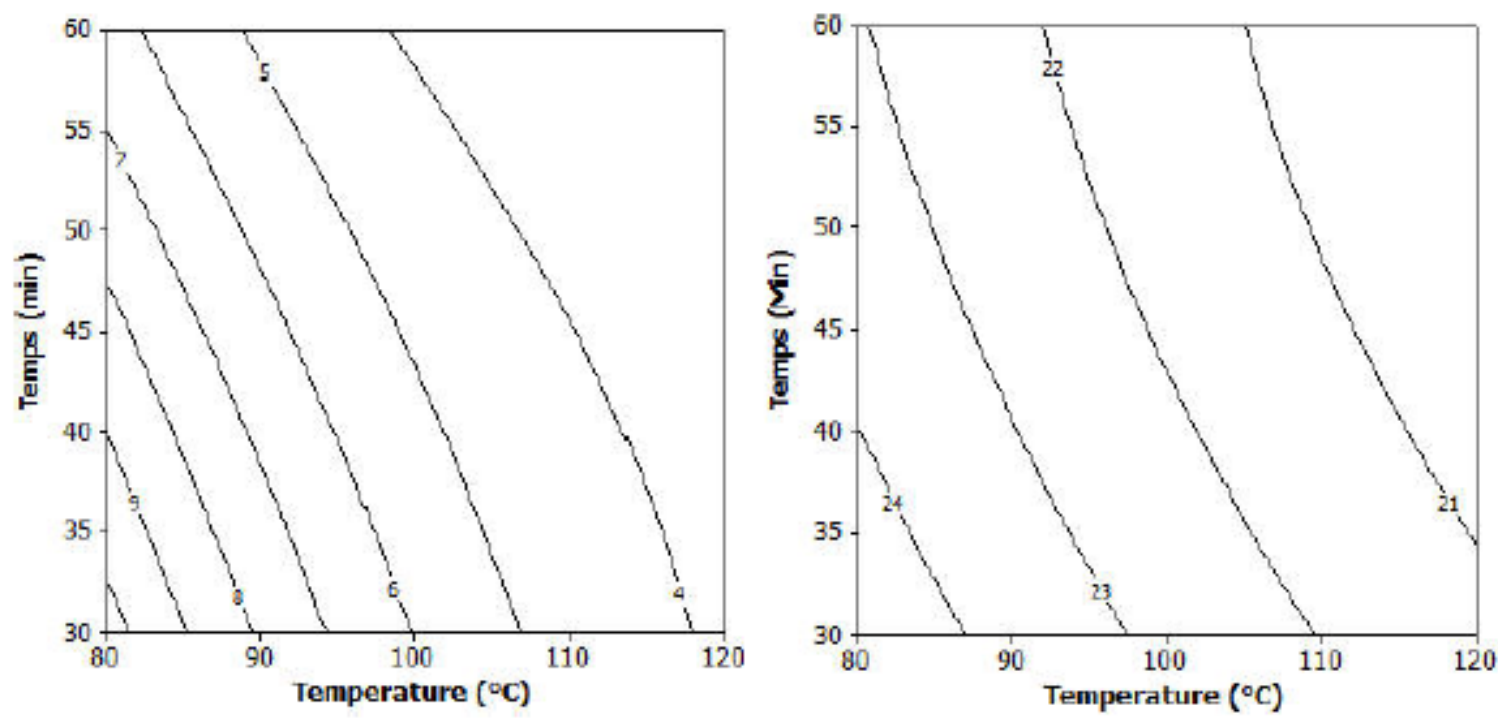

(a)

(c)

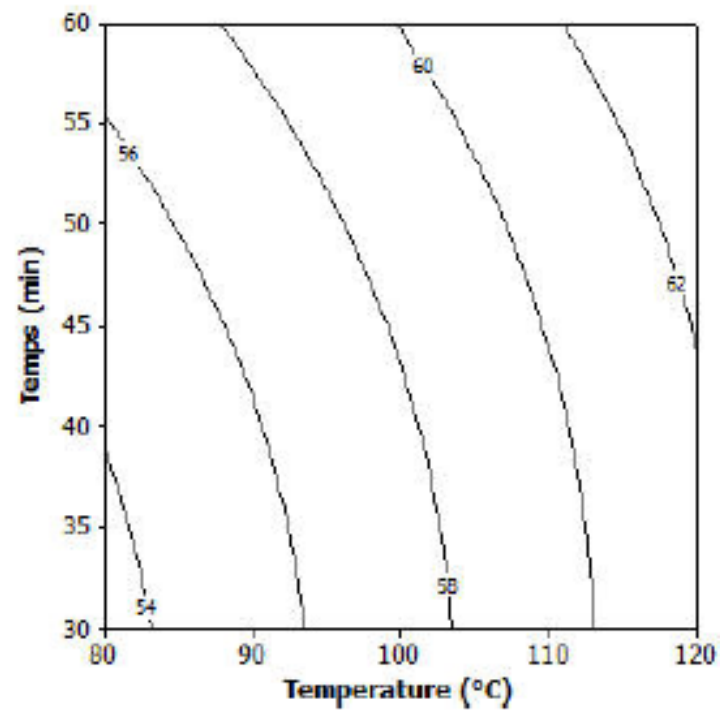

(b)

Figure 1. Contour plots for (a) moisture, (b) protein and (c) lipids of roasted T. catappa almond 


\section{\لMacrothink}

3.2 Effect of Roasting Conditions on Oxalates, Phytates, Tannins, Phenolic Compounds and Flavonoids from the Roasted T. catappa Almond

Antinutritional factors are known to reduce the bioavailability of nutrients and prevent to some point the broad use of several plants due to their ubiquitous occurrence of them as natural compound capable of provoking adverse effect in human and animal (Chlopicka \& Adesina, 2014). The models developed for oxalates, tannins, phytates, phenolic compounds and flavonoids from $T$. catappa almond were obtained as a result to experimental data showed in Table 2a. Results obtained of analysis of variance (Table 3) showed that the responses (oxalates, phytates, tannins, phenolic compounds and flavonoids) were very important $(p \leq 0.001)$ with a lack of fit suggesting that they adequately represented the relationship between the responses and factors.

Oxalates content was linearly linked to roasting temperature $(p<0.001)$ and time $(p<0.05)$, and quadratic effects $(\mathrm{p}<0.05)$ and the interaction effects were trivial (Table 4). Temperature and time, and their quadratic effects are more important than their interaction on the phytates content of T. catappa almonds. Temperature and heating duration, their interaction and their quadratic effects have identical level of importance on the tannins content. Phenolic compounds were linearly related to roasting temperature $(p<0.001)$ and time $(p<0.001)$, and quadratic effects $(p<0.05)$ and the quadratic effects were found to be statistically not significant $(p>0.05)$. Temperature is more important on the flavonoids content whereas time, quadratic and the interaction effects were insignificant $(\mathrm{p}>0.05)$.

According to Figure 2, the content of oxalates decreased with increasing roasting temperature and time. Through roasting, phytates content, tannins, phenolic compounds and flavonoids of $T$. catappa decreased with increasing temperature and time. The lowest oxalates content was obtained at $120{ }^{\circ} \mathrm{C}$ for 60 min of roasting. Oxalates are known to form complexes (calcium oxalate crystals) with minerals, in particular the insoluble chelate complex with dietary calcium. This complexes can hastened around the renal tributes thereby causing renal stones (Ladeji et al., 2004). These results are lower than those found by Jonathan (2015) and Gonzalo (2008) respectively on $T$. catappa almond and soya beans. The decrease in phytate content may be partly due either to the formation of insoluble complexes between phytate (Siddhuraju \& Becker, 2001). The tannins are organic substances capable of forming complexes with macromolecules and particularly with proteins (Hassan, 2011). The reduction in tannins content observed during roasting treatments might be due to the degradation of compounds while treating at a high temperature (Embaby, 2010). The lowest tannins contents obtained in this study is like the one reported by several investigator (Ijeh et al., 2010; Makinde \& Oladunni, 2016) and inferior to those obtained by Jonathan (2015). Flavonoids are the largest class of phenolic compounds, highly reputed for their antioxidative activity (Daniele et al., 2013). According to Scalbert and Williamson (2000), phenolic compounds are widely shared in plant and have many important functional properties in terms of food quality and human health. This decrease in flavonoids and phenolic compounds observed in $T$. catappa almond could be explained to the fact that they are thermolabile (Lemo et al., 2015). These results were in accordance with those indicated by Chlopicka et al. (2012). 

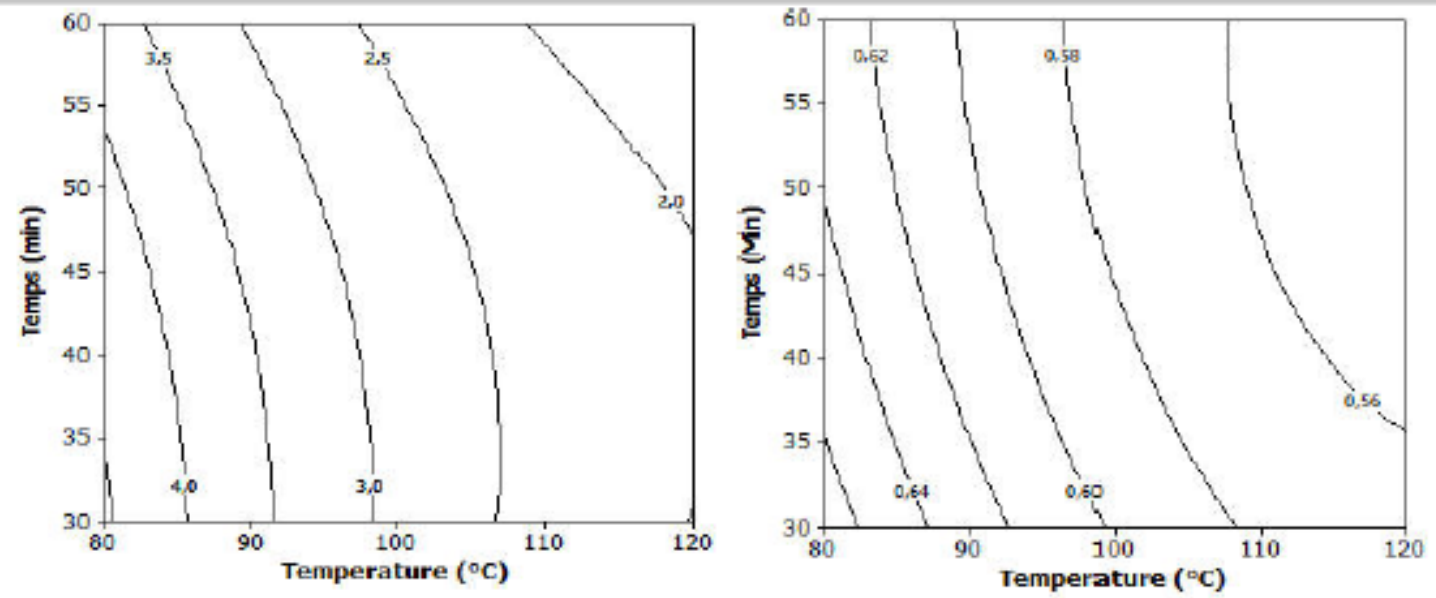

(a)

(b)


(c)

(d)

(e)

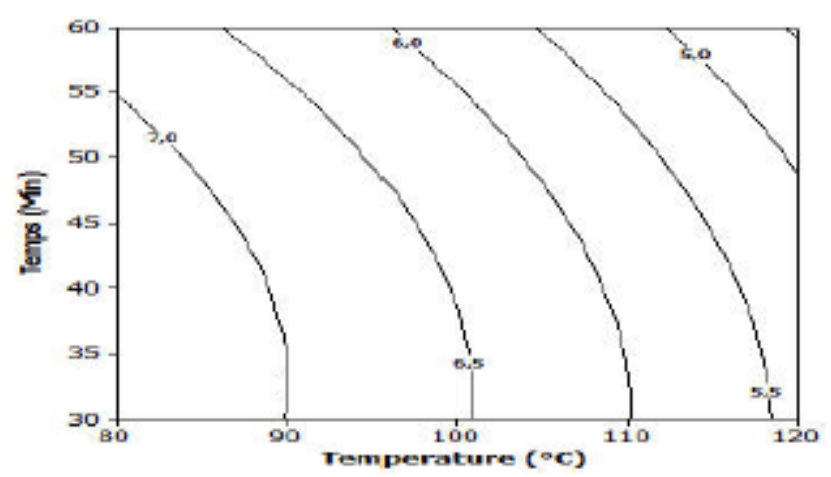

Figure 2. Contour plots for (a) oxalates, (b) phytates, (c) tannins, (d) flavonoids and (e) phenolic compounds of roasted T. catappa almond 


\section{Macrothink}

Journal of Food Studies

ISSN 2166-1073 2020, Vol. 9, No. 1

3.3 Effect of Roasting Conditions on color $\left(L^{*}, a^{*}, b^{*}\right)$ of Oils from the Roasted T. catappa Almond

The regression coefficients of the second-degree for the relationship between roasting conditions and changes of the oil's quality extracted from T. catappa almond are presented in Table $2 \mathrm{~b}$ and 6 . The contour plots for color ( $\mathrm{L}^{*}, \mathrm{a}^{*}$ and $\mathrm{b}^{*}$ ), acid, peroxide and anisidine value then induction period of oils from the roasted T. catappa almond are given in Figure 3 and 4. Results obtained for color indicated that the models developed for three responses ( $\mathrm{L}^{*}$, $a^{*}$ and $b^{*}$ ) were very important (Table 5). Temperature and time did not affect the clarity whereas their interaction had an effect significant $(\mathrm{p}<0.05)$ on $\mathrm{L}^{*}$ value of oils from the roasted T. catappa almond. Temperature had a linear $(\mathrm{p}<0.05)$ effects on $\mathrm{a}^{*}$ value. $\mathrm{b}^{*}$ value of oils was found to be a function of the linear $(\mathrm{p}<0.01)$ effects of roasting temperature and linearly related to time $(\mathrm{p}<0.05)$. According to Figure 3 , the clarity $\left(\mathrm{L}^{*}\right)$ increase and then decrease with increasing roasting temperature and time. This decrease may be due to the fact that roasting may cause the dark color of seeds (Mijena, 2017). Similar results were observed by (Zhao et al., 2012). On the Contrary, $\mathrm{a}^{*}$ and $\mathrm{b}^{*}$ increased with increasing roasting temperature and time. The same results were reported by Özdemir and Devres (2000) and Lee et al. (2004).

Table 2b. Experimental data for response parameters of oil extracted from T. catappa almond in relation to roasting conditions

\begin{tabular}{|c|c|c|c|c|c|c|c|}
\hline \multirow[b]{2}{*}{$\begin{array}{c}\text { Experiment } \\
\text { number }\end{array}$} & \multicolumn{3}{|c|}{ Color } & \multirow{2}{*}{$\begin{array}{l}\text { Acid value } \\
\text { (mg of } \\
\mathrm{KOH} / \mathrm{g} \text { of } \\
\text { oil) }\end{array}$} & \multirow[b]{2}{*}{$\begin{array}{l}\text { Peroxide value } \\
\text { (meq of } \mathrm{O}_{2} / \mathbf{k g} \\
\text { of oil) }\end{array}$} & \multirow[b]{2}{*}{$\begin{array}{c}\text { Anisidine } \\
\text { value }\end{array}$} & \multirow[b]{2}{*}{$\begin{array}{l}\text { Induction } \\
\text { period (h) }\end{array}$} \\
\hline & $\mathbf{L}^{*}$ & $\mathbf{a}^{*}$ & $\mathbf{b}^{*}$ & & & & \\
\hline 1 & 61.56 & -1.25 & 1.56 & 1.11 & 2,75 & 0.01 & 13.42 \\
\hline 2 & 59.01 & -1.30 & 3.61 & 1.54 & 5,41 & 0.05 & 10.85 \\
\hline 3 & 61.97 & -1.22 & 2.19 & 1.28 & 3,88 & 0.01 & 13.46 \\
\hline 4 & 61.36 & -1.25 & 1.71 & 1.39 & 5,39 & 0.23 & 12.60 \\
\hline 5 & 61.97 & -1.22 & 2.19 & 1.28 & 3,88 & 0.01 & 13.46 \\
\hline 6 & 61.97 & -1.21 & 2.19 & 1.29 & 3,88 & 0.01 & 13.46 \\
\hline 7 & 62.15 & -1.19 & 1.94 & 0.41 & 8,33 & 0.003 & 15.33 \\
\hline 8 & 61.56 & -1.25 & 1.56 & 0.85 & 5,96 & 0.011 & 16.08 \\
\hline 9 & 61.48 & -1.16 & 0.99 & 1.01 & 6,40 & 0.001 & 16.61 \\
\hline 10 & 62.23 & -1.28 & 2.96 & 1.65 & 3,80 & 0.002 & 11.71 \\
\hline 11 & 61.56 & -1.25 & 1.56 & 1.97 & 4,34 & 0.011 & 9.80 \\
\hline 12 & 61.97 & -1.21 & 2.19 & 1.29 & 3,88 & 0.012 & 13.46 \\
\hline 13 & 61.97 & -1.21 & 2.19 & 1.28 & 3,88 & 0.011 & 13.46 \\
\hline
\end{tabular}


Table 5. Analysis of variance for quality of oil extracted from T. catappa almond

\begin{tabular}{|c|c|c|c|c|c|c|c|c|}
\hline \multirow{2}{*}{ Source } & \multirow{2}{*}{ Df } & \multicolumn{3}{|l|}{ Color } & \multirow{2}{*}{$\begin{array}{l}\text { Acid } \\
\text { value }\end{array}$} & \multirow{2}{*}{$\begin{array}{l}\text { Peroxide } \\
\text { value }\end{array}$} & \multirow{2}{*}{$\begin{array}{l}\text { Anisidine } \\
\text { value }\end{array}$} & \multirow{2}{*}{$\begin{array}{l}\text { Induction } \\
\text { period (h) }\end{array}$} \\
\hline & & $\mathrm{L}^{*}$ & $a^{*}$ & $\mathrm{~b}^{*}$ & & & & \\
\hline $\begin{array}{l}\text { Regression } \\
\text { model }\end{array}$ & 5 & $6.07^{*}$ & 0.01 & $4.31^{*}$ & $1.68 * * *$ & $20,15^{*}$ & $0.019 * *$ & $43.28 * * *$ \\
\hline Linear & 2 & 1.43 & $0.009 *$ & $3.54 * *$ & $1.67 * * *$ & 8,53 & $0.005 * * *$ & $40.93 * * *$ \\
\hline Square & 2 & 2.03 & 0.0007 & 0.46 & 0.01 & $11,43^{*}$ & $0.013^{*}$ & 0.98 \\
\hline Interaction & 1 & $2.62 *$ & 0.0001 & 0.30 & 0.005 & 0,18 & $0.0004 * *$ & $1.37^{*}$ \\
\hline $\begin{array}{l}\text { Residual } \\
\text { error }\end{array}$ & 7 & 2.11 & 0.006 & 0.99 & 0.04 & 6,51 & 0.027 & 0.89 \\
\hline Lack of fit & 3 & 2.11 & 0.006 & 0.99 & 0.04 & 6,51 & 0.027 & 0.89 \\
\hline Pure error & 4 & 0.00 & 0.00 & 0.00 & 0.00 & 0.00 & 0.00 & 0.00 \\
\hline Total & 12 & 8.19 & 0.017 & 5.31 & 1.72 & 26,66 & 0.047 & 44.18 \\
\hline $\mathbf{R}^{2}$ & & 0.74 & 0.61 & 0.81 & 0.98 & 0,75 & 0.41 & 0.98 \\
\hline
\end{tabular}

$*, * * * * *$ Significant at $\mathrm{p}<0.05, \mathrm{p}<0.01$, and $\mathrm{p}<0.001$, respectively

Table 6. Regression coefficients of the second-degree polynomial for the relationship between roasting conditions and changes in the quality of oils from the roasted T. catappa almond

\begin{tabular}{|c|c|c|c|c|c|c|c|}
\hline \multirow{2}{*}{ Coefficient } & \multicolumn{3}{|l|}{ Color } & \multirow{2}{*}{ Acid value } & \multirow{2}{*}{$\begin{array}{l}\text { Peroxide } \\
\text { value }\end{array}$} & \multirow{2}{*}{$\begin{array}{l}\text { Anisidine } \\
\text { value }\end{array}$} & \multirow{2}{*}{$\begin{array}{l}\text { Induction } \\
\text { period }(\mathrm{h})\end{array}$} \\
\hline & $\mathrm{L}^{*}$ & $a^{*}$ & $b^{*}$ & & & & \\
\hline$P_{0}$ & $62.02 * * *$ & $-1.22 * * *$ & $2.15 * * *$ & $1.28^{* * *}$ & $3,74 * * *$ & $0.07 * *$ & $13.50 * * *$ \\
\hline$P_{1}$ & 0.39 & $0.038^{*}$ & $-0.61^{* *}$ & $-0.48 * * *$ & $1,19^{*}$ & $0,10^{* * *}$ & $2.61^{* * *}$ \\
\hline$P_{2}$ & -0.28 & -0.012 & $0.47^{*}$ & $-0.21 * * *$ & 0,06 & $0,05^{*}$ & 0.09 \\
\hline$\beta_{11}$ & -0.24 & -0.015 & 0.22 & -0.025 & 1,50 & $0,07^{*}$ & $0.29^{*}$ \\
\hline$\beta_{222}$ & -0.67 & -0.0002 & -0.401 & -0.03 & 0,69 & 0.024 & $-0.59^{*}$ \\
\hline$\beta_{12}$ & $0.81^{*}$ & 0.005 & -0.27 & -0.04 & 0,21 & $0,09 * *$ & -0.58 \\
\hline
\end{tabular}

$*, * * * * *$ Significant at $\mathrm{p}<0.05, \mathrm{p}<0.01$, and $\mathrm{p}<0.001$, respectively. 

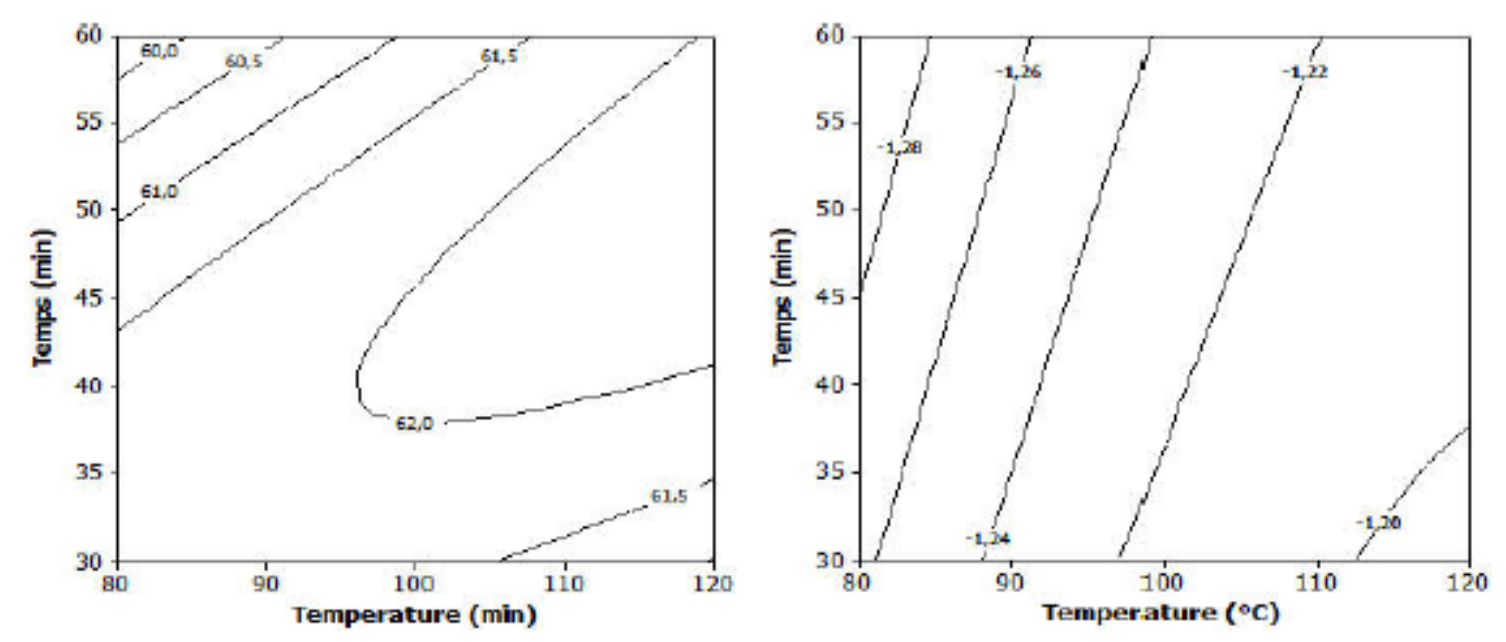

(a)

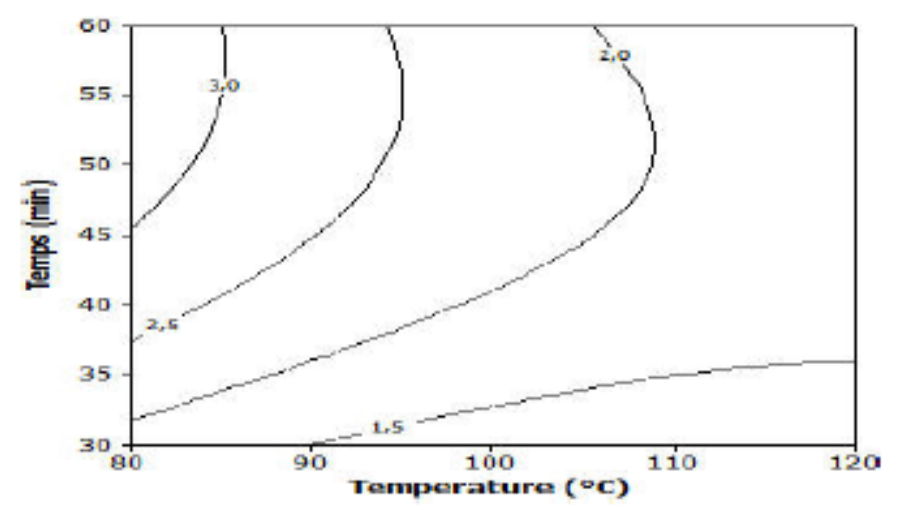

(b)

Figure 3. Contour plots for (a) $\mathrm{L}^{*}$, (b) $\mathrm{a}^{*}$ and (c) $\mathrm{b}^{*}$ of oil extracted from roasted T. catappa almond

3.4 Effect of Roasting Conditions on the Degree of Hydrolysis and Oxidation of Oils from the Roasted T. catappa almond

The criteria commonly used to assess the quality and functionality of the oil include peroxide, acid, anisidine, and iodine value then oxidative stability (Zahir et al., 2017). Except iodine value, the same criteria could be applied to appreciate the quality of oils from the roasted $T$. catappa almond. ANOVA (Table 5) showed that the models developed for the acid value and induction period were significant $(p<0.001)$ with a lack of fit suggesting that the models adequately represented the relationship between the responses and factors. Temperature and time are more important on acid value (Table 6). Temperature is more important on the peroxide value. Temperature and time, their interaction and quadratic effects are more important on the anisidine value. Induction period was linearly related to the temperature of roasting $(\mathrm{p}<0.001)$ and the quadratic $(\mathrm{p}<0.05)$ effects (Table 5).

Based on the regression equations obtained, the contour plots were developed (Figure 4). Acid value of oil decreased with increasing temperature and time during roasting. This could be attributed to the reduction of water content by temperature and time. The same results were reported by Wroniak et al. (2013). This reduction might also be due to the hydrolytic inactivation of enzymes (Ozdemir et al., 2001). Luh et al. (1981) showed that roasting of pistachios at $150^{\circ} \mathrm{C}$ for 30 minutes decreased fatty acids. Peroxide value decreased and then 


\section{Macrothink}

increased with increasing temperature of roasting and time. An increasing may be associated to the inactivation of enzymes responsible for enzymatic oxidation. The same results have been reported by Kita and Figiel (2007) in walnuts oil. Moreover, peroxides are not stable during roasting and may start decomposing when the temperature increases (SchloÈrmann et al., 2015). The decrease observed after roasting does not indicate a lower peroxide value production. it is actually associated with its further conversion to carbonyl compounds with low molecular mass (Das et al., 2014). During roasting, the formation of secondary oxidation products increased with increasing roasting temperature and time. Roasting method significantly $(p<0.05)$ affected the oil anisidine value. Increase in anisidine value of the oil was observed with an increment in both roasting temperature and heating duration (Figure 4c). This could be ossociated to further disaggregation of the less-stable primary oxidative products (hydroperoxides) to form aldehydic compounds (Herchi et al., 2015).

The oxidative stability of plant based oils is influenced by several factors, namely fatty acid composition, antioxidants, mainly tocopherols and minor compounds (Kamal-Eldin, 2006). An enhancement of induction period of oil was observed with increasing roasting temperature and time (Figure 4d). Similar trends were observed in oils of perilla that are produced at other roasting temperatures (Zhao et al., 2012).

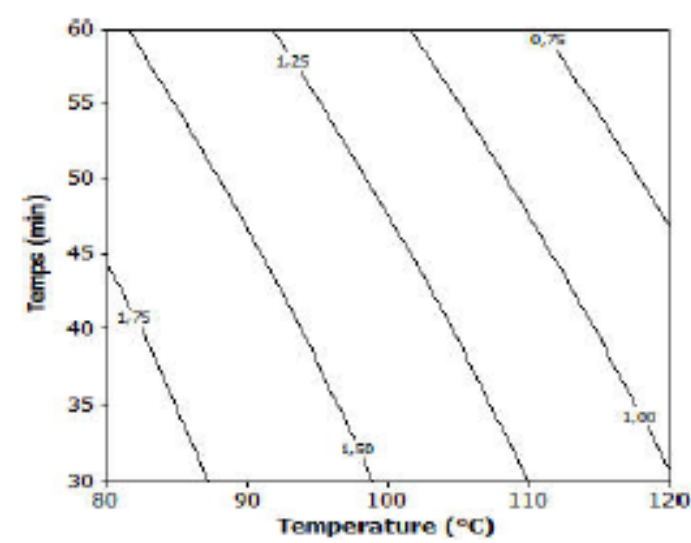

(a)

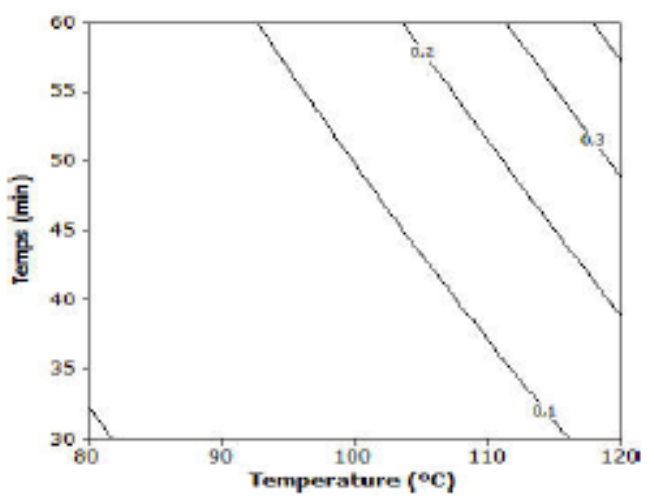

(c)

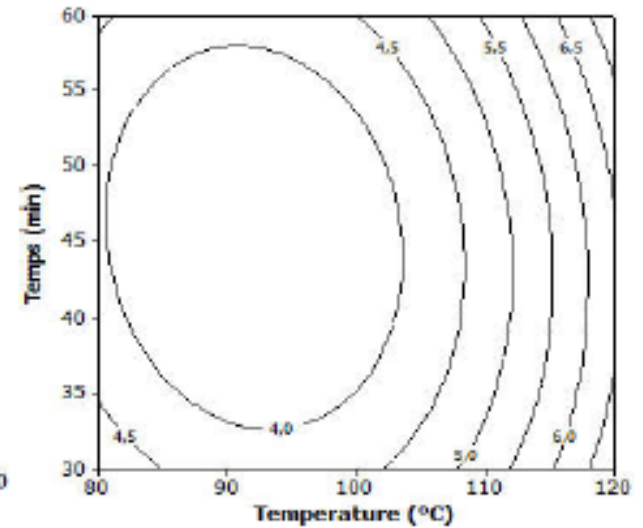

(b)

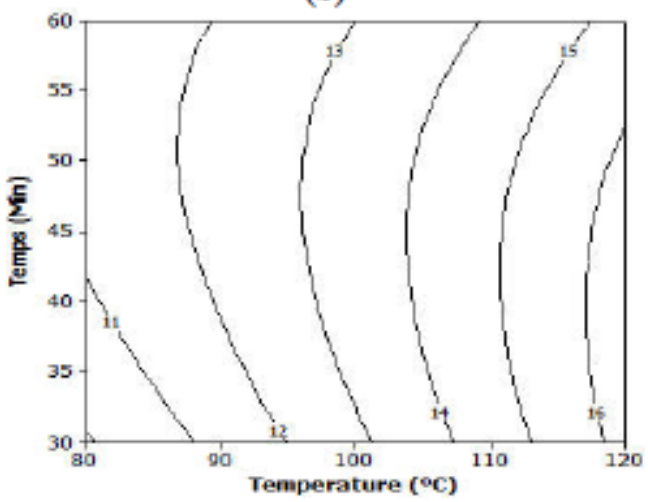

(d)

Figure 4. Contour plots for (a) acid value, (b) peroxide value, (c) anisidine value and (d) induction period of oil extracted from roasted T. catappa almond 


\subsection{Optimum Roasting Conditions and Model Validation}

The results indicate that the optimal roasting temperature and heating duration for reduction of antinutritional factors in almonds were $89.91{ }^{\circ} \mathrm{C}$ and $60 \mathrm{~min}$ with $70.37 \%$ as desirability. The predicted and experimental values at optimum conditions are presented in Table 7 . For the majority responses measured, the experimental values were contrasted with the projected values obtained by the model. Statistical analysis revealed no significant difference $(p \geq 0.05)$ between the predicted and experimental values.

Table 7. Predicted and experimental values at optimum conditions

\begin{tabular}{|c|c|c|c|c|c|}
\hline \multirow{3}{*}{$\begin{array}{c}\text { Response } \\
\text { Moisture content }\end{array}$} & \multirow{3}{*}{$\begin{array}{c}\begin{array}{c}\text { Predicted } \\
\text { value }\end{array} \\
4,85 \mathrm{a}\end{array}$} & \multicolumn{3}{|c|}{ Experimental value } & \multirow{3}{*}{$\begin{array}{c}\text { Desirability }(\mathbf{\%}) \\
0,98\end{array}$} \\
\hline & & \multirow{2}{*}{$\begin{array}{c}\text { Mean } \\
4,89 \mathrm{a}\end{array}$} & \multicolumn{2}{|c|}{ Range } & \\
\hline & & & 4,85 & 4,93 & \\
\hline Oxalates & $2,95 \mathrm{a}$ & $2,82 \mathrm{a}$ & 2,73 & 2,92 & 0,93 \\
\hline Phytates & $0,59 \mathrm{a}$ & $0,58 \mathrm{a}$ & 0,61 & 0,56 & 0,69 \\
\hline Tannins & $0,22 \mathrm{a}$ & $0,22 \mathrm{a}$ & 0,22 & 0,22 & 0,15 \\
\hline Phenolic compound & $6,32 \mathrm{a}$ & $6,25 \mathrm{a}$ & 6,19 & 6,31 & 0.97 \\
\hline Flavonoid & $0,92 \mathrm{a}$ & $0,94 \mathrm{a}$ & 0,99 & 0,89 & 1 \\
\hline Lipid & $58,36 \mathrm{a}$ & $58,97 \mathrm{a}$ & 59,00 & 58,95 & 0.94 \\
\hline Protein & $22,17 \mathrm{a}$ & $21,76 a$ & 22,41 & 21,10 & 1 \\
\hline$L^{*}$ value & $60,39 a$ & $61,18 \mathrm{a}$ & 61,11 & 61,26 & 0.87 \\
\hline$a *$ value & $-1,26 a$ & $-1,255 \mathrm{a}$ & $-1,25$ & $-1,26$ & 0.29 \\
\hline$b^{*}$ value & $2,72 \mathrm{a}$ & $2,665 \mathrm{a}$ & 2,63 & 2,7 & 0.47 \\
\hline Peroxide value & $4,17 \mathrm{a}$ & $3,89 \mathrm{a}$ & 3,99 & 3,79 & 1 \\
\hline Acid value & $1,29 \mathrm{a}$ & $1,23 \mathrm{a}$ & 1,20 & 1,26 & 0.78 \\
\hline p-anisidine value & $0,08 \mathrm{a}$ & $0,07 \mathrm{a}$ & 0,069 & 0,073 & 1 \\
\hline Induction period & $12,05 \mathrm{a}$ & $10,88 \mathrm{a}$ & 10,79 & 10,97 & 0.62 \\
\hline
\end{tabular}

\section{Conclusion}

This study revealed as result that roasting temperature and time significantly impact the nutritional quality of oils and T. catappa almonds. Response surface methodology was effective in producing the predictive models, establishing the relationships between the processing factors (roasting temperature and time) and the responses for the roasting conditions. The optimal combinations of roasting conditions were obtained graphically utilizing contour plots and were $89.91{ }^{\circ} \mathrm{C}$ for $60 \mathrm{~min}$ with $70.37 \%$ as desirability. Statistical analysis showed that predicted and experimental values were not significantly different. These results obtained could be used in the preparation of appetizers concocted and in oleaginous industries.

\section{Acknowledgments}

The research is financed by the West African Economic and Monetary Union. The authors are deeply grateful for the financial support granted to the first author. 


\section{References}

Adu, O. B., Ogundeko, T. O., Ogunrinola, O. O., Saibu, G. M., \& Elemo, B. O. (2015). The effect of thermal processing on protein quality and free amino acid profile of Terminalia catappa (Indian almond) seed. Journal of Food Science and Technology, 52, 4637-4641. https://doi.org/10.1007/s13197-014-1490-8

Kamal-Eldin, A. (2006). Effect of fatty acids and tocopherols on the oxidative stability of vegetable oils Eur. European Journal of Lipid Science and Technology, 108(12), 1051-1061. https://doi.org/10.1002/ejlt.200600090

Agatemor, C., \& Ukhun, M. E. (2006). Nutritional Potential of the Nut of Tropical Almond (Terminalia catappa L.). Pakistan Journal of Nutrition 5(4), 334-336. https://doi.org/10.3923/pjn.2006.334.336

Akpakpan, A. E., \& Akpabio, U. D. (2012). Evaluation of proximate composition , mineral element and anti- nutrient in almond (Terminalia catappa )seeds. Research Journal of Applied Sciences, 7, 489-493. https://doi.org/10.3923/rjasci.2012.489.493

Anhwange, B. A., \& Atoo, G. H. (2015). Proximate Composition of Indigenous Bambara nuts (Vigna subterranean (L.) Verdc). Journal of Pure and Applied Science, 2, 11-16.

Anjum, F., Anwar, F., Jamil, A., \& Iqbal, M. (2006). Microwave Roasting Effects on the Physico-chemical Composition and Oxidative Stability of Sunflower Seed Oil. JAOCS, 83, 777-778. https://doi.org/10.1007/s11746-006-5014-1

AOAC. (1995). Official Methods of.pdf. In: Official Methods of Analysis. Arlington.

AOCS. (2009). Official Methods of.pdf. In: Official Methods of Analysis. Arlington, Sampling and Analysis of Commercial Fats and Oils.

Arinola, S. O., \& Adesina, K. (2014). Effect of Thermal Processing on the Nutritional, Antinutritional, and Antioxidant Properties of Tetracarpidium conophorum (African Walnut). Journal of Food processing, 2014, 2-5. https://doi.org/10.1155/2014/418380

Barku, V. Y. A., Nyarko, H. D., \& Dordunu, P. (2012). Studies on the Physicochemical Characteristics, Microbial Load and Storage Stability of Oil From Indian Almond Nut ( Terminalia Catappa L .). Food Science and Quality Management, 8, 9-18.

Biego, G. H. M., Konan, A. G., Douati, T. E., \& Kouadio, L. P. (2012). Physicochemical Quality of Kernels from Terminalia catappa L. and Sensory Evaluation of the Concocted Kernels. Sustainable Agriculture Research, 1, 1-6. https://doi.org/10.5539/sar.v1n2p1

Embaby, H. E. S. (2010). Effect of Heat Treatments on Certain Antinutrients and in vitro Protein Digestibility of Peanut and Sesame Seeds. Food Science and Technology Research, 17, 31-38. https://doi.org/10.3136/fstr.17.31

Ezeokonkwo, C. (2007). Comparative Effects of Dry- and Moist-Heating Treatments on the Biochemical Characteristics of Terminalia catappa L. Seed. Food Science and Technology International, 13, 165-171. https://doi.org/10.1177/1082013207078066 


\section{Macrothink}

Journal of Food Studies

ISSN 2166-1073

2020, Vol. 9, No. 1

Hossam, E. S., \& EL-Beltagi. (2011). Effect of roasting treatments on protein fraction profiles, some enzyme activities of Egyptian peanuts, International Journal of Food Sciences and Nutrition, 62(5), 453-456. https://doi.org/10.3109/09637486.2010.544642

Oduro I., Larbie, T. N. E., \& Amoako, A. B. (2009). Proximate composition and basic phytochemical assessment of two common varieties of Terminalia catappa (Indian almond). Proximate composition of basic phytochemical assessment, 29, 1-6. https://doi.org/10.4314/just.v29i2.46217

Ijeh, I., Ejike, C. E., Nkwonta, O. M., \& Njoku, B. C. (2011). Effect of Traditional Processing Techniques on the Nutritional and Phytochemical Composition of African Bread-Fruit (Treculia africana) Seeds. Journal of Applied Sciences and Environmental Management, 14, 169-173. https://doi.org/10.4314/jasem.v14i4.63314

Janporn, S., Ho, Chavasit, V., Pan, M. H., Chittrakorn, S., Ruttarattanamongkol, K., \& Weerawatanakorn, M. (2015). Physicochemical properties of Terminalia catappa seed oil as a novel dietary lipid source. Journal of Food and Drug Analysis, 23, 201-209. https://doi.org/10.1016/j.jfda.2014.06.007

Jonathan, A. A. (2015). Effects of roasting on the nutritional and anti-nutritional composition of raw Terminalia catappa L (Tropical almond) Kernels. Malaya Journal of Biosciences, 2, $119-131$

Kachel-jakubowska, M., Kraszkiewicz, A., Koszel, M., \& Przywara, A. (2015). Effects of Thermal Treatment of Seeds on Quality and Oxidative Stability of Oils stability of oils. Agriculture and Agricultural Science Procedia, 7, 255-259.

Kita, A., \& Figiel, A. (2007). Effect of roasting on properties of walnuts. Polish J Food Nutr Sci. 57, 89-94.

Krishnaveni, M. (2014). Phytochemical, Antimicrobial and In vitro Antioxidant activity of Terminalia catappa. Asian journal of Pharmaceutical and Clinical Research, 5, 3325-3329. https://doi.org/10.22159/ajpcr.2019.v12i12.35534

Ladele, B., Kpoviessi, S., Ahissou, H., Gbenou, J., Kpadonou-Kpoviessi, B., Mignolet, E., Hérent, M.F., Bero, J., Larondelle, Y., Quetin-Leclercq, J., \& Moudachirou, M. (2016). Chemical composition and nutritional properties of Terminalia catappa L. oil and kernels from Benin. Comptes Rendus Chimie, 19, 876-883. https://doi.org/10.1016/j.crci.2016.02.017

Lemo, N., Vnuk, D., \& Banović, F. (2015). Observation of potential lidocaine toxicity during local anesthesia administration for punch skin biopsy in dogs. Veterinarski Arhiv, 85, 523-532.

Makinde F. M., \& Oladunni S. S. (2016). Effects of processing treatments on nutritional quality of raw almond (Terminalia catappa Linn.) kernels. Advances in Applied Science Research, Pelagia Research Library Advances, 7, 1-7.

Mbah, B. O., Eme, P. E., \& Eze, C. N. (2013). Nutrient potential of Almond seed (Terminalia catappa) sourced from three states of Eastern Nigeria. African Journal of Agricultural 
Research, 8, 629-633. https://doi.org/10.5897/AJAR

Mijena, R. B. (2017). Optimization of Sesame Roasting Parameters and Level of Ingredients for Sesame Fat Spread Production. International Journal of Nutrition and Food Sciences, 6, 149-157. https://doi.org/10.11648/j.ijnfs.20170604.11

Monthana, W., Supatcha, J., \& Chi-Tang Ho, V.C.I. (2015). Terminalia catappa Linn seeds as a new food source. J. Sci. Technol, 37, 507-514.

Ndidi, U. S., Ndidi, C. U., Aimola, I. A., Bassa, O. Y., Mankilik, M., Adamu, Z., \& Kaduna, N. (2014). Effects of Processing (Boiling and Roasting) on the Nutritional and Antinutritional Properties of Bambara Groundnuts (Vigna subterranea [ L .] Verdc .) from Southern Kaduna, Nigeria. Hindawi Publishing Corporation Journal of Food Processing, 9. https://doi.org/10.1155/2014/472129

Özdemir, M., \& Devres, O. (2000). Analysis of color development during roasting of hazelnuts using response surface methodology. Journal of Food Engineering, 45, 17-24. https://doi.org/10.1016/S0260-8774(00)00036-4

Przybylski, R., \& Eskin, N. A. (2006). Minor components and the stability of vegetable oils. INFORM, 17, 187-189. https://doi.org/10.3989/gya.107912

Santos, I. C. F. dos, Carvalho, S. H. V de, Solleti, J. I., Ferreira de La Salles, W., Teixeira da Silva de La Salles, K., \& Meneghetti, S. M. P. (2008). Studies of Terminalia catappa L. oil: Characterization and biodiesel production. Bioresource Technology, 99, 6545-6549. https://doi.org/10.1016/j.biortech.2007.11.048

SchloÈrmann, W., Birringer, M., BoÈhm, V., LoÈber, K., Jahreis, G., \& Lorkowski, S. (2015). Influence of roasting conditions on health-related compounds in different nuts. Food Chem, 180, 77-85. https://doi.org/10.1016/j.foodchem.2015.02.017

Siddhuraju, P., \& Becker, K. (2001). Effect of Various Domestic Processing Methods on Antinutrients and in Vitro Protein and Starch Digestibility of two Indigenous Varieties of Indian Tribal Pulse, Mucuna pruriens Var. utilis. Journal of Agricultural and Food Chemistryd chemistry, 49, 3058-3067. https://doi.org/10.1021/jf001453q

Zhao, T., Hong, S. I., Lee, J., Lee, J. S., \& Kim, I. H. (2012). Impact of Roasting on the Chemical Composition and Oxidative Stability of Perilla Oil. Journal of Food Science, 77, 1-6. https://doi.org/10.1111/j.1750-3841.2012.02981.x

\section{Copyright Disclaimer}

Copyright for this article is retained by the author(s), with first publication rights granted to the journal.

This is an open-access article distributed under the terms and conditions of the Creative Commons Attribution license (http://creativecommons.org/licenses/by/4.0/). 